\title{
Autumn Leaf Litter and Its Biochar Amendment on Soil Nitrous Oxide Emission, Plant Growth, and Nutrient Uptake of Komatsuna and Spinach Grown in Potted Soils
}

\author{
Aung Zaw Oo ${ }^{1,5}$, Khin Thuar $\mathrm{Win}^{2}$, Daniel Basalirwa ${ }^{3}$, Takeru Gonai ${ }^{4} \&$ Shigeto Sudo ${ }^{1}$ \\ ${ }^{1}$ Institute for Agro-environmental Science, National Agriculture and Food Research Organization, Ibaraki, Japan \\ ${ }^{2}$ National Agriculture and Food Research Organization, Institute of Agrobiological Sciences, Tsukuba, Japan \\ ${ }^{3}$ United Graduate School of Agricultural Sciences, Tottori University, Tottori, Japan \\ ${ }^{4}$ Horticultural Institute, Ibaraki Agricultural Center, Ibaraki, Japan \\ ${ }^{5}$ Japan International Research Center for Agricultural Sciences, Tsukuba, Japan
}

Correspondence: Aung Zaw Oo, Institute for Agro-environmental Science, National Agriculture and Food Research Organization, 3-1-3 Kannondai Tsukuba, Ibaraki, 305-8604, Japan. E-mail: aungzawoo@affrc.go.jp

Shigeto Sudo, Institute for Agro-environmental Science, National Agriculture and Food Research Organization, 3-1-3 Kannondai Tsukuba, Ibaraki, 305-8604, Japan. E-mail: ssudo@affrc.go.jp

Received: October 15, 2019

Accepted: December 2, 2019 Online Published: January 15, 2020

doi:10.5539/jas.v12n2p26

URL: https://doi.org/10.5539/jas.v12n2p26

\begin{abstract}
A pot experiment was conducted to assess the effect of fallen leaf litter and its biochar amendment on vegetable growth and $\mathrm{N}_{2} \mathrm{O}$ emissions from two successive vegetable crops. Four treatments; 1 ) control (no amendment), 2) leaf litter, 3) leaf litter biochar, and 4) combination of leaf litter and biochar were established before planting the first crop (komatsuna) but no additional amendment was done for the second crop (spinach) to assess the residual effects of the treatments. The results showed that application of leaf litter either alone or combined with biochar significantly decreased vegetable yields and nutrient uptake while increasing $\mathrm{N}_{2} \mathrm{O}$ emissions from both crops. Conversion of leaf litter to biochar and its amendment showed no significant differences in vegetable yield, but nutrient uptake was improved when compared with the control. Biochar amendment significantly reduced soil $\mathrm{N}_{2} \mathrm{O}$ emission in the first crop but no significant effect was observed in the successive spinach crop although the amount emitted was less compared with the control. Therefore, conversion of municipal leaf litter to biochar and its amendment to vegetable soils will be one of the best solutions for reducing soil $\mathrm{N}_{2} \mathrm{O}$ emission while maintaining vegetable yield.
\end{abstract}

Keywords: leaf litter, biochar, vegetable crop, greenhouse gas emission, nutrient uptake

\section{Introduction}

Global vegetable fields account for about $7 \%$ of the total croplands, and the percentages are usually higher in developed countries ( $\mathrm{Li} \&$ Wang, 2007). The main features of vegetable fields are high $\mathrm{N}$ application rates, intensive production and management practices such as frequent irrigation and tillage, and multiple crop cycles during the year (Rezaei Rashti et al., 2015). Due to high N fertilizer applications with a high cropping index, intensive vegetable cultivation is considered to be an important source of $\mathrm{N}_{2} \mathrm{O}$ from vegetated soil. Therefore, it is important to reduce $\mathrm{N}_{2} \mathrm{O}$ emission induced by $\mathrm{N}$ fertilizer under multiple crop cycles in one year while increasing vegetable yield under different management practices.

Nitrous oxide is a potent greenhouse gas with a long lifetime, and it has a global warming potential 296 times stronger than $\mathrm{CO}_{2}$ over a time horizon of 100 years (IPCC, 2013). Due to the widespread use of synthetic nitrogen fertilizer, agricultural soil is the single largest source of $\mathrm{N}_{2} \mathrm{O}$ emission, and it is estimated at $3.9 \mathrm{Tg} \mathrm{N}$ $\mathrm{yr}^{-1}$ (FAOSTAT, 2014). However, there is a considerable mitigation potential in agriculture sector (IPCC, 2014), which can change the large emitter to a much smaller emitter even a net sink origination from soil carbon sequestration (Bellarby et al., 2008). 
In urban areas, there is dumping of enormous quantities of leaf litter that accumulates in the garden, along the roads, backyard, playground and lawns which has always been a major problem (Singh et al., 2017). Leaf litter from these sources might dispose of by burning or landfilling which causes adverse impacts on the environment. Instead, leaf litter can be used as an organic amendment due to its potential to act as a nutrient source for vegetable production. However, addition of leaf litter could affect crop yield and quality due to high carbon content (Soumare et al., 2012), but it will largely depend on the type of organic amendment and decomposition stage. Moreover, the use of leaf litter as soil amendment might affect $\mathrm{N}_{2} \mathrm{O}$ emission from vegetable soil.

Recently, biochar production from residues and its application in soil as a soil amendment is a novel approach as a soil improver, carbon sequestration, soil fertility improvement and crop production (Jeffery et al., 2017) and decrease greenhouse gas emission (Fan et al., 2017; Oo et al., 2018a). Biochar amendment affects $\mathrm{C}$ and $\mathrm{N}$ turnover by influencing microbial community structure and biomass (Singla et al., 2014), and hence alters soil $\mathrm{N}_{2} \mathrm{O}$ emissions (Fiedel et al., 2007). However, other studies have reported positive, negative, or negligible effects of biochar on $\mathrm{N}_{2} \mathrm{O}$ emissions from soils (Van Zwieten et al., 2010; Clough et al., 2010; Saarnio et al., 2013; Cayuela et al., 2013; Oo et al., 2018b). The previous results pointed out that it is still necessary to study the effect of specific type of biochar made from specific method on crop growth and greenhouse gas emission from amended soils. In this study, biochar obtained from autumn fallen leaf litter was used to study its effect on vegetable growth, nutrient uptake and $\mathrm{N}_{2} \mathrm{O}$ emission from two successive vegetable crops. The objectives of this study were to (1) evaluate the effect of leaf litter and its biochar amendment on $\mathrm{N}_{2} \mathrm{O}$ emissions during two continuous vegetable cycles and (2) to study their effects on soil properties, growth, and ion uptake of tested vegetables.

\section{Materials and Methods}

\subsection{Experimental Soil}

The soil used in this study was collected from an upland field at the Horticultural Research Institute of the Agricultural Research Center in Ibaraki Prefecture, Ibaraki, Japan. The studied soil, an Andosol (United States Department of Agriculture, USDA classification), is the most common arable soil in Japan and about $82 \%$ of vegetables are grown on Andosol in Ibaraki prefecture alone. A composite soil sample collected from the top 0 to $20 \mathrm{~cm}$ layer was air-dried and plant debris were removed. The experimental soil was classified as a silk loam and composed of $24.7 \%$ sand, $50.4 \%$ silt, $22.9 \%$ clay, pH $5.3\left(1: 5 \mathrm{H}_{2} \mathrm{O}\right), \mathrm{EC} 0.1 \mathrm{mS} \mathrm{cm}^{-1}$, total N $3.7 \mathrm{~g} \mathrm{~kg}^{-1}$, total C $45 \mathrm{~g} \mathrm{~kg}^{-1}, \mathrm{P}_{2} \mathrm{O}_{5} 41 \mathrm{mg} \mathrm{kg}^{-1}, \mathrm{~K}_{2} \mathrm{O} 459 \mathrm{mg} \mathrm{kg}^{-1}$, bulk density $0.76 \mathrm{~g} \mathrm{~cm}^{-3}$ (Oo et al., 2018c).

\subsection{Leaf Litter and Biochar Preparation}

During mid-December 2018, autumn leaf litter from maple trees was collected at the Institute for Agro-environmental Science, National Agriculture and Food Research Organization, Tsukuba, Japan. Some collected leaf litter were shredded and put in the bucket to allow decomposition of leaf litter during winter months before growing the vegetable crop. However, due to cold weather during the winter period, it was only partially decomposed, and the litter was still fresh. The leaf litter had a $\mathrm{pH}\left(\mathrm{H}_{2} \mathrm{O}\right)$ of 5.4, EC $2.5 \mathrm{mS} \mathrm{cm}^{-1}$, total N $6.5 \mathrm{~g} \mathrm{~kg}^{-1}$, total $\mathrm{C} 433.9 \mathrm{~g} \mathrm{~kg}^{-1}$, and $\mathrm{C} / \mathrm{N}$ ratio of 66.8 . Leaf litter biochar was produced from carbonization of maple leaf litter under open fire using open burn kiln with pyrolysis temperature of approximately $500-600{ }^{\circ} \mathrm{C}$ (Oo et al., 2018b). The biochar had a pH $\left(\mathrm{H}_{2} \mathrm{O}\right)$ of 9.3 , EC $2.1 \mathrm{mS} \mathrm{cm}^{-1}$, total $\mathrm{N} 5.1 \mathrm{~g} \mathrm{~kg}^{-1}$, total C $381.2 \mathrm{~g} \mathrm{~kg}^{-1}$, and $\mathrm{C} / \mathrm{N}$ ratio of 74.8 .

\subsection{Experimental Design and Set-Up}

A pot experiment was conducted at the Institute for Agro-Environmental Sciences, National Agriculture and Food Research Organization. Four treatments were arranged in a completely randomized design with three replications for two successive vegetable crops; komatsuna (Brassica rapa) and spinach (Spinacia oleracea). The treatments were 1) control, 2) leaf litter, 3) leaf litter biochar, and 4) combination of leaf litter and biochar. The leaf litter and biochar application rates were $52.7 \mathrm{~g}$ and $60 \mathrm{~g} \mathrm{pot}^{-1}$, respectively. For leaf litter plus biochar treatment, leaf litter of $26.4 \mathrm{~g}$ and biochar of $30 \mathrm{~g}$ was mixed with the soil. The pots used in this study (1/5000a Wagner pot, height $20 \mathrm{~cm}$, and diameter $16 \mathrm{~cm}$ ) were filled with $3 \mathrm{~kg}$ of air-dried soil. For treatments, all the added leaf litter and biochar were mixed thoroughly with soils. There were two crop cycles; komatsuna was planted during the first crop cycle from $27^{\text {th }}$ March and harvested on $25^{\text {th }}$ April, while spinach was planted in the second crop cycle after harvest of komatsuna on $28^{\text {th }}$ April and harvested on $4^{\text {th }}$ July. For each crop, N (urea), P (triple superphosphate), and K (muriate of potash) fertilizers were applied at the same rate of $120 \mathrm{~kg} \mathrm{ha}^{-1}$ for all pots before planting each crop. However, leaf litter and biochar were applied only once before planting the first crop and then, the residual effect of these amendments were studied in the second crop. 
For the first crop, seeds of komatsuna were sown in seedling trays in the greenhouse and they emerged four days after seeding. The 14-day old seedlings were transplanted carefully with one seedling per pot. Soon after harvesting komatsuna, direct seeding of spinach was done with three seeds per pot and later thinned to one seedling 7 days after emergence. Watering was done every two or three days depending on the conditions to maintain similar soil moisture content during both crop periods.

\subsection{Sample Collections and Analyses}

The gas samples used to determine $\mathrm{N}_{2} \mathrm{O}$ concentrations were collected using the closed chamber method. The pots were covered with a small chamber and gas samples were collected at 0,10 , and $20 \mathrm{~min}$ after closure. The sampled gases were then transferred to $15-\mathrm{mL}$ vacuum glass vials. The concentrations of $\mathrm{N}_{2} \mathrm{O}$ were analyzed with a gas chromatograph (GC 2014, Shimadzu Corporation, Kyoto, Japan) equipped with an electron capture detector (ECD). The $\mathrm{N}_{2} \mathrm{O}$ fluxes were calculated by examining the linear regression of the concentrations at each sampling time. The seasonal total $\mathrm{N}_{2} \mathrm{O}$ emissions from all pots were calculated by successive linear interpolation of average gas emissions on the sampling days.

Soil temperature was recorded at the time of gas sampling. After harvest of each crop, top soil samples were collected for analysis of soil properties. The soil $\mathrm{pH}\left(\mathrm{H}_{2} \mathrm{O}\right)$ was measured using a $\mathrm{pH}$ meter (Mettler Toledo, FiveEasy, FE 20, Mettler Toldedo, Tokyo, Japan). Soil total carbon and nitrogen contents were measured using a NC analyzer (Sumigraph NC-80; Sumika Chemical Analysis Service Co., Japan).

At harvest for each crop, plant height, shoot dry weight, root length and root dry weight were recorded. To determine the nutrient uptake in both crops, the shoot samples were dried and ground and later digested in concentrated nitric acid, and the volume made up to $10 \mathrm{ml}$ with milli-Q water. Mineral element contents in plant extracts were analyzed by atomic absorption spectrophotometer (Shimadzu AA-6300, Tokyo, Japan) and UV-Vis spectrophotometer (Shimadzu UV-1800, Tokyo, Japan). Mineral element uptakes for both crops were calculated using the equation: mineral element uptake $\left(\mathrm{mg} \mathrm{pot}^{-1}\right)=$ dry mater weight $\left(\mathrm{mg} \mathrm{pot}^{-1}\right) \mathrm{X}$ mineral content of shoot dry matter $(\%)$.

All data were analyzed by analysis of variance (ANOVA) by using Statistical Tool for Agricultural Research (STAR), International Rice Research Institute, IRRI, Philippines. When significant, treatment mean comparison was done using the least significant difference (LSD) test at $\mathrm{P} \leq 5 \%$.

\section{Results and Discussion}

\subsection{Variations in Soil Temperature, $p H$, Soil Total $N$ and C Contents}

During the first crop period, soil temperatures were generally low, ranging from 9.8 to $19.6{ }^{\circ} \mathrm{C}$ but in the second crop, soil temperature ranged from 13.3 to $27.5^{\circ} \mathrm{C}$ which was low during the early period and then gradually increased by the end of spinach growing period (Figure 1). The lower soil temperatures during the komatsuna growing period could be attributed to the low temperatures that occur during early spring as compared to the relatively higher temperatures during the spinach growing period which occurred in late spring. There were no significant differences in soil temperatures among the treatments for both the komatsuna and Spinach growing periods. High temperature fluctuation especially during the komatsuna growing period was directly related to weather conditions on the different sampling dates. 

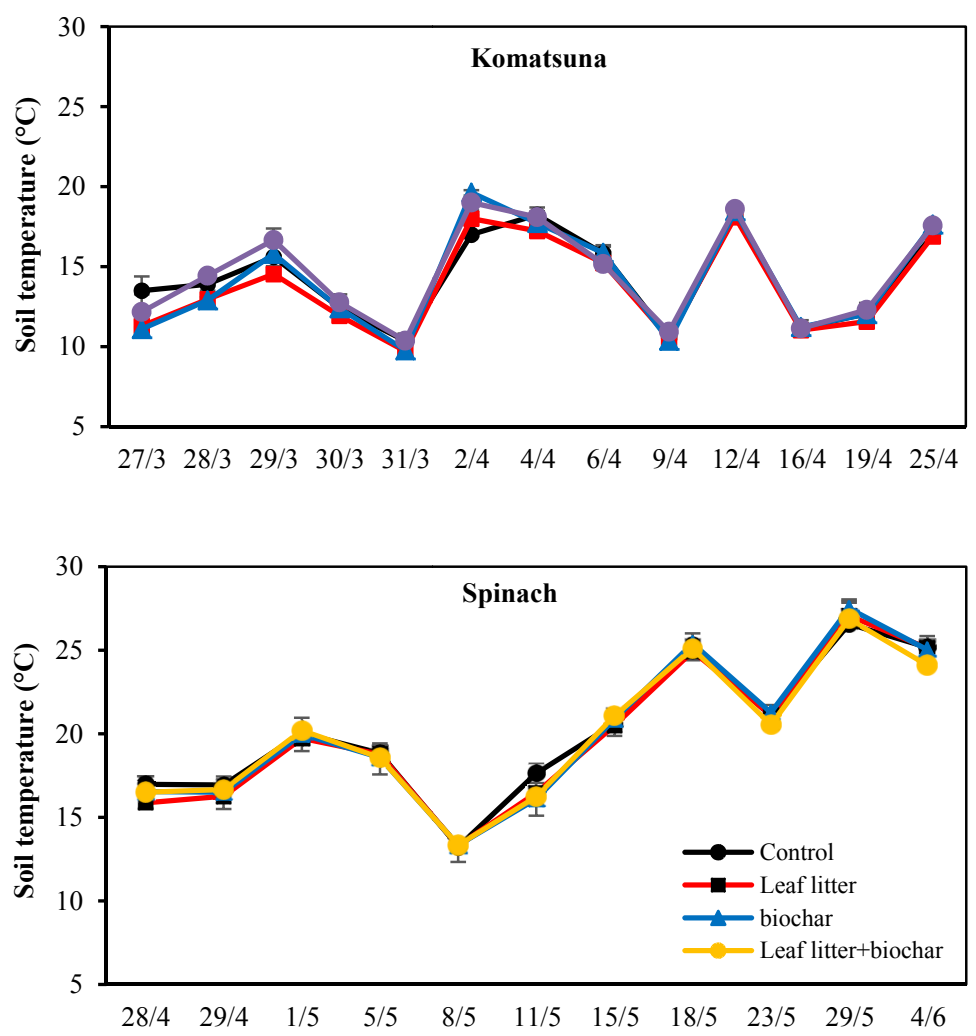

Figure 1. Changes in soil temperature during the two crop growing seasons under fallen leaves and/or biochar amendment. Error bars indicate standard deviation

There were significant $(p<0.05)$ differences in soil $\mathrm{pH}$ among the treatments after harvest of both crops (Table 1). Leaf litter biochar amendment showed significant increase in soil $\mathrm{pH}$ compared with control, but opposite effect was observed under leaf litter amendment. Other studies also reported increase in soil $\mathrm{pH}$ under biochar amendment due to the high pH of biochar (Van Zwieten et al., 2010; Oo et al., 2018a). Combine application of leaf litter and its biochar also increased soil $\mathrm{pH}$, significant effect was only observed after harvest of spinach crop. In both crop seasons, soil $\mathrm{pH}$ increased by 0.1 and 0.23 units after harvest of komatsuna and spinach, respectively, following biochar amendment.

There was no significant $(p>0.05)$ difference in soil total $\mathrm{N}$ content at the end of both crops. Soil total $\mathrm{C}$ content was significantly $(p<0.05)$ affected by leaf litter and its biochar amendment (Table 1$)$. After harvest of first crop, soil total C increased by $13.5,30.1$, and $19.0 \%$ for leaf litter, biochar and leaf litter plus biochar amendment, respectively, compared to the control. After harvest of second crop, due to the residual effect of leaf litter and biochar, soil total C content was still increased by $9.7,16.7$, and $15.4 \%$ for leaf litter, biochar and leaf litter plus biochar amendment. The results of Pietsch et al. (2018) also showed that addition of aged biochar still increased soil organic carbon contents which is two times higher than control. However, soil total C content was lowered after harvest of spinach compared with its content after first crop harvest. 
Table 1. Effect of leaf litter and/or biochar on properties of soil after harvest of komatsuna and spinach

\begin{tabular}{|c|c|c|c|c|c|c|c|c|}
\hline & \multicolumn{4}{|c|}{ After harvest of komatsuna } & \multicolumn{4}{|c|}{ After harvest of spinach } \\
\hline & $\mathrm{pH}\left(\mathrm{H}_{2} \mathrm{O}\right)$ & $\begin{array}{l}\text { Total N } \\
\left(\mathrm{g} \mathrm{kg}^{-1}\right)\end{array}$ & $\begin{array}{l}\text { Total C } \\
\left(\mathrm{g} \mathrm{kg}^{-1}\right)\end{array}$ & $\mathrm{C}: \mathrm{N}$ ratio & $\mathrm{pH}\left(\mathrm{H}_{2} \mathrm{O}\right)$ & $\begin{array}{l}\text { Total N } \\
\left(\mathrm{g} \mathrm{kg}^{-1}\right)\end{array}$ & $\begin{array}{l}\text { Total C } \\
\left(\mathrm{g} \mathrm{kg}^{-1}\right)\end{array}$ & $\mathrm{C}: \mathrm{N}$ ratio \\
\hline Control & $6.86 \pm 0.06 \mathrm{~b}$ & $4.75 \pm 0.21$ & $51.97 \pm 2.15 \mathrm{c}$ & $10.9 \pm 0.03 \mathrm{c}$ & $6.69 \pm 0.09 \mathrm{~b}$ & $3.88 \pm 0.13$ & $46.2 \pm 1.5 \mathrm{c}$ & $11.9 \pm 0.01 \mathrm{c}$ \\
\hline Leaf litter & $6.73 \pm 0.03 \mathrm{c}$ & $4.86 \pm 0.41$ & $59.02 \pm 2.43 \mathrm{~b}$ & $12.2 \pm 0.76 \mathrm{~b}$ & $6.65 \pm 0.08 \mathrm{~b}$ & $3.83 \pm 0.06$ & $50.7 \pm 1.4 \mathrm{~b}$ & $13.3 \pm 0.58 \mathrm{~b}$ \\
\hline Biochar (BC) & $6.96 \pm 0.03 \mathrm{a}$ & $4.68 \pm 0.08$ & $67.62 \pm 5.84 \mathrm{a}$ & $14.4 \pm 1.10 \mathrm{a}$ & $6.92 \pm 0.08 \mathrm{a}$ & $3.88 \pm 0.10$ & $53.9 \pm 1.6 \mathrm{a}$ & $13.9 \pm 0.08 \mathrm{a}$ \\
\hline Litter + BC & $6.94 \pm 0.04 \mathrm{ab}$ & $4.69 \pm 0.04$ & $61.84 \pm 1.00 \mathrm{ab}$ & $13.2 \pm 0.12 \mathrm{ab}$ & $6.86 \pm 0.07 \mathrm{a}$ & $3.91 \pm 0.04$ & $53.3 \pm 0.2 \mathrm{a}$ & $13.6 \pm 0.10 \mathrm{ab}$ \\
\hline \multicolumn{9}{|c|}{ Analysis of variance } \\
\hline Treatment & $* *$ & Ns & $* *$ & $* *$ & $* *$ & ns & $* *$ & $* *$ \\
\hline
\end{tabular}

Note. Values are mean \pm standard deviation. Means followed by the same letters in column are not significantly different at the $\mathrm{P} \leq 5 \%$ level by the LSD test.

After harvest of each crop, soil C:N ratio was significantly $(p<0.05)$ affected by leaf litter and its biochar amendment (Table 1). Soil C:N ratio increased by 11.9, 32.1, and $21.1 \%$ after harvest of komatsuna and by 11.8 , 16.8 , and $14.3 \%$ after harvest of spinach for leaf litter, biochar, and leaf litter + biochar, respectively, compared to the control. Feng and Zhu (2017) and Oo et al. (2018c) reported that changes in soil C content and C:N ratio might be a key parameter influencing soil $\mathrm{N}$ utilization which will affect vegetable growth and soil $\mathrm{N}_{2} \mathrm{O}$ emission under leaf litter and/or biochar amendment in this study.

\subsection{Growth and Nutrient Uptake of Komatsuna and Spinach}

There were significant $(p<0.05)$ differences in all measured plant growth parameters except root length of both crops (Table 2). Leaf litter amendment showed lower plant height, shoot and root dry weight for both crops when compared with control. Soumare et al. (2012) also showed that high dose of Euclayptus litter caused depressive effects on growth and yield of groundnut probably due to high carbon content $(45.5 \%)$ when compared with maize litter amendment (37.5\%). In this study, decrease in crop growth under leaf litter amendment was due to high carbon content because of low decomposition stage of leaf litter with high C:N ratio. With large C:N ratio of amended leaf litter, most of the applied $\mathrm{N}$ is immobilized after application of organic matter, and therefore crop yield was lowered not only in the first crop also in the next crop season. Under organic amendment, Hodge et al. (2000) discussed that if $\mathrm{N}$ immobilization interfered with plant growth, the probability was high that microorganisms were more competitive for nutrients than plants if plant and microbial $\mathrm{N}$ uptake occurred simultaneously in the same soil volume. The inhibitory effect of organic amendment such as compost on plant growth might be associated with the release of phytotoxic compounds, including short-chain organic acids, tannins and phenols (Tiquia, 2010; Scotti et al., 2015). Other studies also reported that application of carbon rice organic residues such as wheat straw might lower crop yield due to immobilization of available $\mathrm{N}$ in soil after application of organic residues (Cheshire et al., 1999). However, Sarkar et al. (2010) stated that forest leaf litters showed its significant positive effect on yield and nutrient uptake by red amaranth. Different effect of organic amendment on crop yield might be due to the use of different organic sources with varying decomposition rates.

Biochar containing treatments showed no differences in plant height of komatsuna but significantly decreased the plant height of the successive spinach crop. Although, we expected an increase vegetable yield, shoot dry weight was not affected by biochar treatment in both crops. However, other studies have reported that biochar amendment improved soil properties and soil fertility through microbial community and therefore increasing crop production (Chan \& Xu, 2009; Novak et al., 2009). In our previous study with komatsuna crop using orchard pruning residue biochar, increase in shoot dry weight compared with control was due to improve soil quality such as increased soil $\mathrm{pH}$, total $\mathrm{N}$, improve soil porosity and decrease bulk density of soil under biochar amendment (Oo et al., 2018c). No differences in vegetable yield under leaf litter biochar amendment was probably due to high C:N ratio of leaf litter biochar in this study. Jeffery et al. (2017) reported that crop yield improvement under biochar amendment was largely dependent on nutrient content of biochar used and high-nutrient biochar inputs stimulated yield substantially more than low-nutrient biochar in tropical soils. However, they discussed that arable soils in temperate regions are moderate in soil $\mathrm{pH}$, higher in soil fertility, and generally receive higher fertilizer inputs, leaving little room for additional benefits from biochar amendment.

Significant $(p<0.05)$ decrease in shoot dry weight of spinach was observed under combined application of biochar and leaf litter. Although no difference $(p>0.05)$ in root length was observed, leaf litter significantly ( $p<$ $0.05)$ decreased root dry weight of both crops. Biochar amendment significantly $(p<0.05)$ increased root dry weight of komatsuna and spinach, but no interaction effect with leaf litter was observed on root dry weight. 
Table 2. Effect of leaf litter and/or biochar on shoot and root growth of Komatsuna and spinach

\begin{tabular}{|c|c|c|c|c|c|c|c|c|}
\hline & \multicolumn{4}{|c|}{$1^{\text {st }}$ crop-Komatsuna } & \multicolumn{4}{|c|}{$2^{\text {nd }}$ crop-Spinach } \\
\hline & $\begin{array}{l}\text { Plant height } \\
(\mathrm{cm})\end{array}$ & $\begin{array}{l}\text { Shoot dry wt. } \\
\left(\mathrm{g} \mathrm{pot}^{-1}\right)\end{array}$ & $\begin{array}{l}\text { Root length } \\
(\mathrm{cm})\end{array}$ & $\begin{array}{l}\text { Root dry wt. } \\
\left(\mathrm{g} \mathrm{pot}^{-1}\right)\end{array}$ & $\begin{array}{l}\text { Plant height } \\
(\mathrm{cm})\end{array}$ & $\begin{array}{l}\text { Shoot dry wt. } \\
\left(\mathrm{g} \mathrm{pot}^{1}\right)\end{array}$ & $\begin{array}{l}\text { Root length } \\
(\mathrm{cm})\end{array}$ & $\begin{array}{l}\text { Root dry wt. } \\
\left(\mathrm{g} p o t^{-1}\right)\end{array}$ \\
\hline Control & $13.1 \pm 0.4 \mathrm{a}$ & $4.11 \pm 0.11 \mathrm{a}$ & $22.7 \pm 1.5$ & $0.52 \pm 0.04 \mathrm{~b}$ & $14.7 \pm 0.2 \mathrm{a}$ & $1.84 \pm 0.25 \mathrm{a}$ & $16.2 \pm 3.0$ & $0.18 \pm 0.02 \mathrm{~b}$ \\
\hline Leaf litter & $8.6 \pm 0.7 \mathrm{~b}$ & $2.66 \pm 0.21 \mathrm{~b}$ & $22.4 \pm 1.6$ & $0.37 \pm 0.03 \mathrm{c}$ & $9.0 \pm 0.5 \mathrm{~d}$ & $0.51 \pm 0.07 \mathrm{~b}$ & $15.3 \pm 3.3$ & $0.08 \pm 0.03 \mathrm{c}$ \\
\hline Biochar (BC) & $14.0 \pm 0.7 \mathrm{a}$ & $4.40 \pm 0.22 \mathrm{a}$ & $24.2 \pm 1.6$ & $0.64 \pm 0.06 \mathrm{a}$ & $13.2 \pm 1.1 \mathrm{~b}$ & $1.80 \pm 0.53 \mathrm{a}$ & $20.5 \pm 4.3$ & $0.25 \pm 0.04 \mathrm{a}$ \\
\hline Litter + BC & $13.2 \pm 0.9 \mathrm{a}$ & $4.15 \pm 0.30 \mathrm{a}$ & $23.7 \pm 1.0$ & $0.56 \pm 0.07 \mathrm{ab}$ & $11.2 \pm 0.8 \mathrm{c}$ & $0.73 \pm 0.02 \mathrm{~b}$ & $20.5 \pm 2.9$ & $0.14 \pm 0.03 \mathrm{bc}$ \\
\hline \multicolumn{9}{|c|}{ Analysis of variance } \\
\hline Treatment & $* *$ & $* *$ & ns & $* *$ & $* *$ & $* *$ & ns & $* *$ \\
\hline
\end{tabular}

Note. Values are mean \pm standard deviation. Means followed by the same letters in column are not significantly different at the $\mathrm{P} \leq 5 \%$ level by the LSD test.

Although there was no effect on shoot dry weight, leaf litter biochar amendment significantly $(p<0.05)$ increased plant uptake of N, P, and K in the first crop, komatsuna (Table 3). High N uptake of vegetable crops grown in biochar amended soils were also reported by Van Zwieten et al. (2010) and Chan et al. (2008). Increased in $\mathrm{P}$ and $\mathrm{K}$ uptake under biochar amendment might be due to the content of these elements in biochar. Kloss et al. (2012) discuss that fresh biochar might contain significant amounts of soluble P and K, which contribute to the plant available pool upon incorporation in the soil and therefore increased uptake of $\mathrm{P}$ and $\mathrm{K}$ with biochar amendment. Although $\mathrm{P}$ and $\mathrm{K}$ uptake of spinach was still higher due to the residual effects of biochar, the effect was not significant. This meant that the significant effects of biochar on major nutrient uptake faded in successive crop. Although, both $\mathrm{Mg}$ and $\mathrm{Ca}$ uptake of komatsuna were not affected by biochar amendment, Mg uptake of spinach was significantly affected by residual effect of biochar. The high $\mathrm{K}$ content in biochar could lead to luxury consumption of $\mathrm{K}$ in plant tissues thereby adversely affecting $\mathrm{Ca}$ and $\mathrm{Mg}$ nutrition (Butnan et al., 2015; Wacal et al., 2019). This could partly explain the negative effect of biochar on Mg uptake in spinach. Leaf litter amendment decreased all measured nutrients uptake in both crops (Table 3). Poor crop growth under leaf litter amendment might associated with low nutrient uptake of komatsuna and spinach. However, Sarkar et al. (2010) reported that leaf litter improved nutrient content of red amaranth, but it was largely depended on type of leaf litter used.

Table 3. Effect of leaf litter and/or biochar on total mineral nutrient uptake of komatsuna and spinach

\begin{tabular}{|c|c|c|c|c|c|}
\hline & \multicolumn{5}{|c|}{ Nutrient uptake $\left(\mathrm{mg} \mathrm{pot}^{-1}\right)$} \\
\hline & $\mathrm{N}$ & $\mathrm{P}$ & $\mathrm{K}$ & $\mathrm{Mg}$ & $\mathrm{Ca}$ \\
\hline \multicolumn{6}{|l|}{ Komatsuna } \\
\hline Control & $128.6 \pm 7.9 \mathrm{~b}$ & $6.5 \pm 0.3 \mathrm{bc}$ & $106.8 \pm 19.7 \mathrm{~b}$ & $13.7 \pm 1.1 \mathrm{a}$ & $111.1 \pm 2.4 \mathrm{a}$ \\
\hline Leaf litter & $65.3 \pm 20.2 \mathrm{c}$ & $5.1 \pm 0.9 \mathrm{c}$ & $54.5 \pm 18.6 \mathrm{c}$ & $8.2 \pm 1.8 \mathrm{~b}$ & $61.3 \pm 14.8 \mathrm{~b}$ \\
\hline Biochar & $164.4 \pm 2.7 \mathrm{a}$ & $8.2 \pm 0.8 \mathrm{a}$ & $133.1 \pm 5.2 \mathrm{a}$ & $15.5 \pm 2.0 \mathrm{a}$ & $106.1 \pm 6.6 \mathrm{a}$ \\
\hline Leaf litter + biochar & $107.5 \pm 16.8 \mathrm{~b}$ & $7.1 \pm 0.9 \mathrm{ab}$ & $93.0 \pm 12.0 \mathrm{~b}$ & $13.3 \pm 1.5 \mathrm{a}$ & $98.8 \pm 19.9 \mathrm{a}$ \\
\hline \multicolumn{6}{|l|}{ Analysis of variance } \\
\hline Treatment & $* *$ & $* *$ & $* *$ & $* *$ & $* *$ \\
\hline \multicolumn{6}{|l|}{ Spinach } \\
\hline Control & $45.4 \pm 7.7 \mathrm{a}$ & $2.9 \pm 0.3 \mathrm{~b}$ & $54.1 \pm 4.3 \mathrm{a}$ & $12.8 \pm 2.5 \mathrm{a}$ & $19.9 \pm 5.3 \mathrm{a}$ \\
\hline Leaf litter & $9.3 \pm 1.3 \mathrm{~b}$ & $1.2 \pm 0.2 \mathrm{c}$ & $16.6 \pm 2.3 \mathrm{~b}$ & $2.3 \pm 0.5 \mathrm{c}$ & $8.6 \pm 1.9 \mathrm{~b}$ \\
\hline Biochar & $43.8 \pm 12.8 \mathrm{a}$ & $4.8 \pm 1.4 \mathrm{bc}$ & $65.7 \pm 18.8 \mathrm{a}$ & $9.3 \pm 2.6 \mathrm{~b}$ & $22.2 \pm 6.7 \mathrm{a}$ \\
\hline Leaf litter + biochar & $16.3 \pm 0.5 \mathrm{a}$ & $2.6 \pm 0.1 \mathrm{a}$ & $28.5 \pm 0.6 \mathrm{~b}$ & $3.2 \pm 0.1 \mathrm{c}$ & $9.8 \pm 0.3 \mathrm{~b}$ \\
\hline \multicolumn{6}{|l|}{ Analysis of variance } \\
\hline Treatment & $* *$ & $* *$ & $* *$ & $* *$ & $* *$ \\
\hline
\end{tabular}

Note. Values are mean \pm standard deviation. Means followed by same letters in column are not significantly different at the $\mathrm{P} \leq 5 \%$ level by the LSD test.

\section{$3.3 \mathrm{~N}_{2} \mathrm{O}$ Emissions}

During the first crop, $\mathrm{N}_{2} \mathrm{O}$ emission showed increasing trend and first peak emission occurred in all treatments during the first week after planting of komatsuna (Figure 2). This result was in accordance with Azam et al. 
(2002). Short-lived increase in $\mathrm{N}_{2} \mathrm{O}$ flux suggested that $\mathrm{N}$ fertilizer and decomposition of crop residues can provide a temporary abundance of $\mathrm{C}$ and $\mathrm{N}$ to microorganisms resulting in a rapid increase in $\mathrm{N}_{2} \mathrm{O}$ emission (Azam et al., 2002). After that peak, biochar alone and control treatments showed decreasing trend to the end of the growing period. However, leaf litter alone or combined with biochar remained high in $\mathrm{N}_{2} \mathrm{O}$ emission with the second peak occurring three weeks after planting, after which emission showed a decreasing trend up to the end of the crop period. Other studies also reported an increase in $\mathrm{N}_{2} \mathrm{O}$ emissions under organic residue amendment (Henderson et al., 2010).

In contrast to the first crop, high emission peaks occurred within a few days after planting (Figure 2b). And then, a sharp decrease in $\mathrm{N}_{2} \mathrm{O}$ emission was observed within one week after transplanting. An increase in $\mathrm{N}_{2} \mathrm{O}$ emission soon after basal application in both crop seasons indicated that added organic matter and nitrifiable nitrogen were the main source of $\mathrm{N}_{2} \mathrm{O}$ production. After early emission peak, $\mathrm{N}_{2} \mathrm{O}$ emissions remained steady until the end of the growing period. Gao et al. (2016) discussed that the activity of microorganisms and substrate $\mathrm{N}$ decreased with $\mathrm{C}$ and $\mathrm{N}$ consumption over a certain period, and therefore $\mathrm{N}_{2} \mathrm{O}$ emission decreased to background levels.
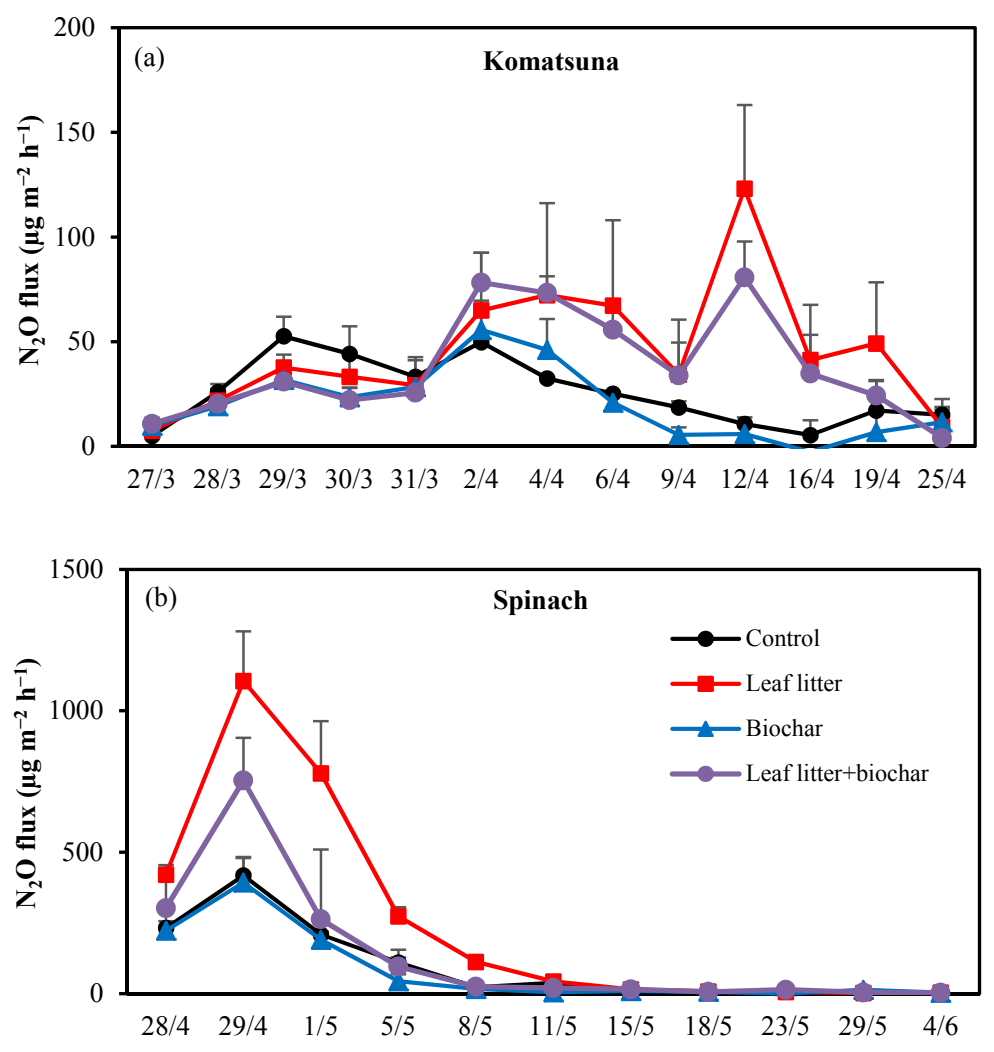

Figure 2. Seasonal pattern of $\mathrm{N}_{2} \mathrm{O}$ emissions during the two vegetable growing seasons under leaf litter and/or biochar amendment. Error bar-standard deviation. Note* Y-axes values for two crops were different

There were significant $(p<0.05)$ differences in cumulative soil $\mathrm{N}_{2} \mathrm{O}$ emission among the treatments in both crop seasons (Figure 3). Cumulative $\mathrm{N}_{2} \mathrm{O}$ emission from leaf litter, and combined application of leaf litter and biochar amendment significantly $(p<0.05)$ increased by $138.0 \%$ and $83.7 \%$ in komatsuna, respectively, and by $175.4 \%$ and $38.6 \%$ in spinach compared with their respective controls. Increase in $\mathrm{N}_{2} \mathrm{O}$ emissions under organic residue amendments were also reported by other studies (Henderson et al., 2010; Miller et al., 2008; Gillam et al., 2008; Oo et al., 2018c). Organic residue amendment increased $\mathrm{N}_{2} \mathrm{O}$ emissions from agricultural soils in Europe due to increase denitrification stimulated by the added substrate and the creation of anaerobic micro sites by increased soil respiration (Lehtinen et al., 2014). However other studies reported the negative effect on soil $\mathrm{N}_{2} \mathrm{O}$ emissions (Ma et al., 2007) and the effect largely depended on C:N ratio of the residue. Muhammad et al. (2011) discussed that plant residues enhanced soil $\mathrm{N}_{2} \mathrm{O}$ emissions by inducing higher concentration of dissolved organic carbon and this enhancement was quantitatively dependent on C:N ratio of the residues. In this study, incorporation of 
leaf litter might provide a source of readily available $\mathrm{C}$ and $\mathrm{N}$ in the soil for both crop seasons, and subsequently influences the $\mathrm{N}_{2} \mathrm{O}$ emission from both crops. Therefore, the enhanced $\mathrm{N}_{2} \mathrm{O}$ emissions by organic fertilizers were attributed to increased availability of labile organic $\mathrm{C}$, which serves as an energy source for microbial activity (Senbayram et al., 2012) and creates a more anoxic environment for denitrification (Van Groenigen et al., 2005).

However, addition of leaf litter biochar decreased $\mathrm{N}_{2} \mathrm{O}$ emission by $25.6 \%$ and $38.5 \%$ in komatsuna and spinach, respectively, compared with their respective controls but the significant effect was observed only in komatsuna crop (Figure 3). The reduction in $\mathrm{N}_{2} \mathrm{O}$ emission by leaf litter biochar amendment might be due to an increase in soil $\mathrm{pH}$, total $\mathrm{C}$ and $\mathrm{C}: \mathrm{N}$ ratio of soils (Table 1). Liu et al. (2010) discussed that increased in the assembly of functional $\mathrm{N}_{2} \mathrm{O}$ reductase activity (the enzyme that reduces $\mathrm{N}_{2} \mathrm{O}$ to $\mathrm{N}_{2}$ during the process of denitrification) due to high soil $\mathrm{pH}$ under biochar amendment might be the reason for reduced $\mathrm{N}_{2} \mathrm{O}$ emission. As the relative $\mathrm{C}$ content increases in soil, the $\mathrm{N}$ demand of microbes increases above the $\mathrm{N}$ availability and $\mathrm{N}$ becomes a limiting factor relative to $\mathrm{C}$ for nitrification or denitrification and, thus, $\mathrm{N}_{2} \mathrm{O}$ emission becomes relatively low (Feng \& Zhu, 2017).

Although a reduction in $\mathrm{N}_{2} \mathrm{O}$ emission was observed in the second crop due to the residual effect of biochar, effect of aged biochar on soil $\mathrm{N}_{2} \mathrm{O}$ emission was no statistically significant compared with the control (Figure $3 b)$. Many studies have also conducted the effect of aged biochar on soil $\mathrm{N}_{2} \mathrm{O}$ emissions under field and lab conditions, but the results were inconsistent. Hagemann et al. (2017) reported that 3-year field-aged biochar effectively reduced $\mathrm{N}_{2} \mathrm{O}$ emissions but other studies stated that biochar lost its initial ability to suppress soil $\mathrm{N}_{2} \mathrm{O}$ emissions after 1-year field aging (Felber et al., 2014). However, Duan et al. (2018) observed that aged biochar amendment stimulated soil $\mathrm{N}_{2} \mathrm{O}$ production in acidic and alkaline soils by stimulating soil nitrification and denitrification. Due to physico-chemical behavioral changes of biochar by geochemical weathering process during biochar aging, soil nitrogen dynamics and microbial activity were affected differently which directly affect soil $\mathrm{N}_{2} \mathrm{O}$ emissions (Mia et al., 2017). Therefore, different effect of aged biochar on soil $\mathrm{N}_{2} \mathrm{O}$ emissions will largely be depended on type and aged of biochar and soil type.

The higher $\mathrm{N}_{2} \mathrm{O}$ emissions observed in the spinach growing period was mainly attributed to the basal $\mathrm{N}$ fertilizer added at the start of the growing period in addition to the residual fertilizer that could have remained in the previous crop growth period of komatsuna. The action of nitrifiers and/or denitrifiers is increased in higher temperature than low temperature conditions (Gödde \& Conrad, 1999; Braker et al., 2010) and this could also account for the high $\mathrm{N}_{2} \mathrm{O}$ emissions in the spinach growing period. 

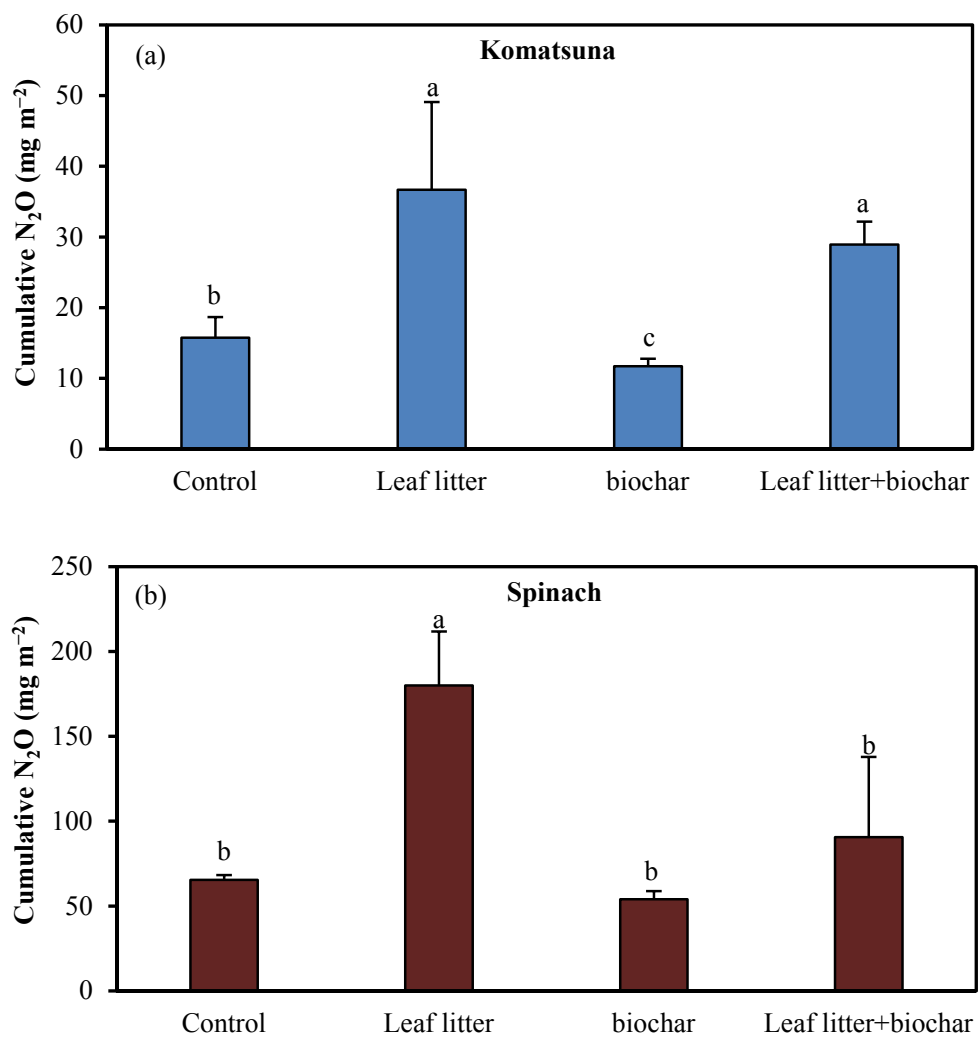

Figure 3. Cumulative $\mathrm{N}_{2} \mathrm{O}$ emissions affected by leaf litter and its biochar. Error bars indicate standard deviation. Means with the same letters are not significantly different at the $\mathrm{P} \leq 5 \%$ level by the LSD

\section{Conclusion}

Application of autumn leaf litter, either alone or combined with biochar, not only increased soil $\mathrm{N}_{2} \mathrm{O}$ emissions also affected the growth of komatsuna and spinach. The results suggested that fresh organic matter should not applied directly to vegetated soil to avoid high $\mathrm{N}_{2} \mathrm{O}$ emissions and yield reduction. Conversion of accumulated autumn leaf litter into biochar might be one of the solutions for municipal wastes while reducing $\mathrm{N}_{2} \mathrm{O}$ emissions after its amendment to soils. However, this study conducted only short period with two successive vegetable crops, further research is needed to investigate the effects of leaf litter biochar on vegetable growth and $\mathrm{N}_{2} \mathrm{O}$ emissions under field conditions.

\section{References}

Azam, F., Müller, C., Weiske, A., Benckiser, G., \& Ottow, J. (2002). Nitrification and denitrification as sources of atmospheric nitrous oxide-role of oxidizable carbon and applied nitrogen. Biology and Fertility of Soils, 35(1), 54-61. https://doi.org/10.1007/s00374-001-0441-5

Bellarby, J., Foereid, B., \& Hastings, A. (2008). Cool Farming: Climate Impacts of Agriculture and Mitigation Potential. Greenpeace International: Amsterdam, The Netherlands. Retrieved from https://eprints.lancs.ac. uk/id/eprint/68831/1/1111.pdf

Braker, G., Schwarz, J., \& Conrad, R. (2010). Influence of temperature on the composition and activity of denitrifying soil communities. FEMS Microbiology Ecology, 73(1), 134-148. https://doi.org/10.1111/ j.1574-6941.2010.00884.x

Butnan, S., Deenik, J. L., Toomsan, B., Antal, M. J., \& Vityakon, P. (2015). Biochar characteristics and application rates affecting corn growth and properties of soils contrasting in texture and mineralogy. Geoderma, 237-238, 105-116. https://doi.org/10.1016/j.geoderma.2014.08.010

Cayuela, M. L., Sa'nchez-Monedero, M. A., Roig, A., Hanley, K., Enders, A., \& Lehmann, J. (2013). Biochar and denitrification in soils: When, how much and why does biochar reduce $\mathrm{N}_{2} \mathrm{O}$ emissions? Scientific Report, 1732. https://doi.org/10.1038/srep01732 
Chan, K.Y., Van Zwieten, L., Meszaros, I., Downie, A., \& Joseph, S. (2008). Using poultry litter biochars as soil amendments. Australian Journal of Soil Research, 46, 437-444. https://doi.org/10.1071/SR08036

Chan, K. Y., \& Xu, Z. H. (2009). Biochar: Nutrient Properties and Their Enhancement. In J. Lehmann, \& S. Joseph (Eds.), Biochar for Environmental Management: Science and Technology (5th ed., pp. 67-84). UK: Earthscan. https://doi.org/10.4324/9781849770552-12

Cheshire, M. V., Bedrock, C. N., Williams, B. L., Chapman, S. J., Solntseva, I., \& Thomsen, I. (1999).The immobilization of nitrogen by straw decomposing in soil. European Journal of Soil Science, 50, $329-341$. https://doi.org/10.1046/j.1365-2389.1999. 00238.x

Clough, T. J., Bertram, J. E., Ray, J. L., Condron, L. M., O’Callaghan, M., Sherlock, R. R., \& Wells, N. S. (2010). Unweathered wood biochar impact on nitrous oxide emissions from a bovine-urine-amended pasture soil. Soil Science Society of American Journal, 74, 852-860. https://doi.org/10.2136/sssaj2009.0185

Duan, P., Zhang, X., Zhang, Q., Wu, Z., \& Siong, Z. (2018). Field-aged biochar stimulated N2O production from greenhouse vegetable production soils by nitrification and denitrification. Sci. of the Total Environment, 642, 1303-1310. https://doi.org/10.1016/j.scitotenv.2018.06.166

Fan, C., Chen, H., Li, B., \& Xiong, Z. (2017). Biochar reduces yield-scaled emissions of reactive nitrogen gases from vegetable soils across China. Biogeosciences, 14, 2851-2863. https://doi.org/10.5194/bg-142851-2017

FAOSTAT. (2014). Faostat Agric. Data. Retrieved from http//faostat3.fao.org/faostat-gateway/go/to/download/ $\mathrm{G} 1 / \mathrm{GY} / \mathrm{E}$

Felber, R., Leifeld, J., Horák, J., \& Neftel, A. (2014). Nitrous oxide emission reduction with green waste biochar: Comparison of laboratory and field experiments. European Journal of Soil Science, 65, 128-138. https://doi.org/10.1111/ejss.12093

Feng, Z., \& Zhu, L. (2017). Impact of biochar on soil $\mathrm{N}_{2} \mathrm{O}$ emissions under different biochar-carbon/fertilizer-nitrogen ratios at a constant moisture condition on a silt loam soil. Science of the Total Environment, 15, 584-585. https://doi.org/10.1016/j.scitotenv.2017.01.115

Fidel, R. B., Laird, D. A., \& Parkin, T. B. (2017). Impact of Biochar Organic and Inorganic Carbon on Soil $\mathrm{CO}_{2}$ and $\mathrm{N}_{2} \mathrm{O}$ Emissions. Journal of Environmental Quality, 46, 505-513. https://doi.org/10.2134/jeq2016. 09.0369

Gao, J., Xie, Y., Jin, H., Liu, Y., Bai, X., Ma, D., ... Guo, T. (2016). Nitrous oxide emission and dentrifier abundance in two agricultural soils amended with crop residues and urea in the north China plain. PloS One 11(5), e0154773. https://doi.org/10.1371/journal.pone.0154773

Gillam, K. M., Zebarth, B. J., \& Burton, D. L. (2008). Nitrous oxide emissions from denitrification and the partitioning of gaseous losses as affected by nitrate and carbon addition and soil aeration. Canadian Journal of Soil Science, 88, 133-143. https://doi.org/10.4141/CJSS06005

Gödde, M., \& Conard, R. (1999). Immediate and adaptational temperature effects on nitric oxide production and nitrous oxide release from nitrification and denitrification in two soils. Biology and Fertility of Soils, 30, 33-40. https://doi.org/10.1007/s003740050584

Hagemann, N., Harter, J., Kaldamukova, R., Guzman-Bustamante, I., Ruser, R., Graeff, S., ... Behrens, S. (2017). Does soil aging affect the $\mathrm{N}_{2} \mathrm{O}$ mitigation potential of biochar? A combined microcosm and field study. Global Change Biology and Bioenergy, 9, 953-964. https://doi.org/10.1111/gcbb.12390

Henderson, S. L., Dandie, C. E., Patten, C. L., Zebrath, B. J., Burton, D. L., Trevors, J. T., \& Goyer, C. (2010). Changes in denitrifier abundance, denitrification gene mRNA levels, nitrous oxide emissions, and denitrification in anoxic soil microcosms amended with glucose and plant residues. Applied Environmental Microbiology, 76, 2155-2164. https://doi.org/10.1128/AEM.02993-09

Hodge, A., Robinson, D., \& Fitter, A. (2000). Are microorganisms more effective than plants at competing for nitrogen? Trends in Plant Science, 5, 304-308. https://doi.org/10.1016/s1360-1385(00)01656-3

IPCC (Intergovernmental Panel on Climate Change). (2013). Climate Change 2013: The Physical Science Basis. Contribution of Working Group I to the Fifth Assessment Report of the Intergovernmental Panel on Climate Change. Cambridge University Press: Cambridge, UK; New York, NY, USA.

IPCC (Intergovernmental Panel on Climate Change). (2014). Climate Change 2014: Synthesis Report. Contribution of Working Groups I, II and III to the Fifth Assessment Report of the Intergovernmental Panel 
on Climate Change, Technical Report. IPCC: Geneva, Switzerland. https://doi.org/10.1017/CBO97811 07415416

Jeffery, S., Abalos, D., Prodana, M., Bastos, A., van Groenigen, J. W., Hungate, B., \& Verheijen, F. (2017). Biochar boosts tropical but not temperate crop yields. Environmental Research Letter, 12, 053001. https://doi.org/10.1016/s1360-1385(00)01656-3

Kloss, S., Zehetner, F., Dellantonio, A., Hamid, R., Ottner, F., Liedtke, V., ... Soja, G. (2012). Characterization of slow pyrolysis biochars: Effects of feedstocks and pyrolysis temperature on biochar properties. Journal of Environmental Quality, 41, 990-1000. https://doi.org/10.2134/jeq2011.0070

Lehtinen, T., Schlatter, N., Baumgarten, A., Bechini, L., Krüger, J., Grignani, C., ... Spiegel, H. (2014). Effect of crop residue incorporation on soil organic carbon and greenhouse gas emissions in European agricultural soils. Soil Use and Management, 30, 524-538. https://doi.org/10.1111/sum.12151

Li, D., \& Wang, X. (2007). Nitric oxide emission from a typical vegetable field in the Pearl River Delta, China. Atmospheric Environment, 41, 9498-9505. https://doi.org/10.1016/j.atmosenv.2007.08.042

Liu, B., Morkved, P. T., Frostegard, A., \& Bakken, L. R. (2010). Denitrification gene pools, transcription and kinetics of $\mathrm{NO}, \mathrm{N}_{2} \mathrm{O}$ and $\mathrm{N}_{2}$ production as affected by soil pH. FEMS Microbial Ecology, 72, 407-417. https://doi.org/10.1111/j.1574-6941.2010.00856.x

Ma, J., Li, X., Xu, H., Han, Y., Cai, Z., \& Yagi, K. (2007). Effects of nitrogen fertilizer and wheat straw application on $\mathrm{CH}_{4}$ and $\mathrm{N} 2 \mathrm{O}$ emissions from a paddy rice field. Australian Journal of Soil Research, 45, 359-367. https://doi.org/10.1071/SR07039

Mia, S., Dijkstra, F. A., \& Singh, B. (2017). Aging induced changes in Biochar`s functionality and adsorption behavior for phosphate and ammonium. Environmental Science Technology, 51, 8359-8367. https://doi.org/10.1021/acs.est.7b00647

Miller, M. N., Zebarth, B. J., Dandie, C. E., Burton, D. L., Goyer, C., \& Trevors, J. T. (2008). Crop residue influence on denitrification, $\mathrm{N}_{2} \mathrm{O}$ emissions and denitrifier community abundance in soil. Soil Biology and Biochemistry, 40, 2553-2562. https://doi.org/10.1016/j.soilbio.2008.06.024

Muhammad, W., Vaughan, S. M., Dalal, R. C., \& Menzies, N. W. (2011). Crop residues and fertilizer nitrogen influence residue decomposition and nitrous oxide emission from a Vertisol. Biology and Fertility of Soils, 47, 15-23. https://doi.org/10.1007/s00374-010-0497-1

Novak, J. M., Busscher, W. J., Laird, D. L., Ahmedna, M., Watts, D. W., \& Niandou, M. A. S. (2009). Impact of biochar amendment on fertility of a Southeastern coastal plain soil. Soil Science, 174, 105-112. https://doi.org/10.1097/SS.0b013e3181981d9a

Oo, A. Z., Sudo, S., Akiyama, H., Win, K. T., Shibata, A., Yamamoto, A., ... Sano, T. (2018a). Effect of dolomite and biochar addition on $\mathrm{N}_{2} \mathrm{O}$ and $\mathrm{CO}_{2}$ emissions from acidic tea field soil. PLoS ONE, 13, E0192235. https://doi.org/10.1371/journal.pone.0192235

Oo, A. Z., Sudo, S., Win, K. T., Shibata, A., \& Gonai, T. (2018b). Influence of pruning waste biochar and oyster shell on $\mathrm{N}_{2} \mathrm{O}$ and $\mathrm{CO}_{2}$ emissions from Japanese pear orchard soil. Heliyon, 4, e00568. https://doi.org/ 10.1016/j.heliyon.2018.e00568

Oo, A. Z., Sudo, S., Win, K. T., Shibata, A., Sano, T., \& Hirono, Y. (2018c). Returning Tea Pruning Residue and Its Biochar Had a Contrasting Effect on Soil $\mathrm{N}_{2} \mathrm{O}$ and $\mathrm{CO}_{2}$ Emissions from Tea Plantation Soil. Atmosphere, 9, 109. https://doi.org/10.3390/atmos9030109

Paetsch, L., Mueller, C. W., Kögel-Knabner, I., von Lützow, M., Girardin, C., \& Rumpel, C. (2018). Efect of in-situ aged and fresh biochar on soil hydraulic conditions and microbial $\mathrm{C}$ use under drought conditions. Scientific Reports, 8, 6852. https://doi.org/10.1038/s41598-018-25039-x

Rezaei Rashti, M. R., Wang, W., Moody, P., Chen, C., \& Ghadiri, H. (2015). Fertiliser-induced nitrous oxide emissions from vegetable production in the world and the regulating factors: A review. Atmospheric Environment, 112, 225-233. https://doi.org/10.1016/j.atmosenv.2015.04.036

Saarnio, S., Heimonen, K., \& Kettunen, R. (2013). Biochar addition indirectly affects $\mathrm{N}_{2} \mathrm{O}$ emissions via soil moisture and plant N uptake. Soil Biology and Biochemistry, 58, 99-106. https://doi.org/10.1016/ j.soilbio.2012.10.035 
Sarkar, U. K., Saha, B. K., Goswami, C., \& Chowdhury, M. A. H. (2010). Leaf litter amendment in forest soil and their effect on the yield quality of red amaranth. Journal of Bangladesh Agriculture University, 8(2), 221-226. https://doi.org/10.3329/jbau.v8i2.7929

Scotti, R., Bonanomi, G., Scelza, R., Zoina, A., \& Rao, M. A. (2015). Organic amendments as sustainable tool to recovery fertility in intensive agricultural systems. Journal of Soil Science and Plant Nutrition, 15(2). https://doi.org/10.4067/S0718-95162015005000031

Senbayram M., Chen, R., Budai, A., Bakken, L., \& Dittert, K. (2012). $\mathrm{N}_{2} \mathrm{O}$ emission and the $\mathrm{N}_{2} \mathrm{O} /\left(\mathrm{N}_{2} \mathrm{O}+\mathrm{N}_{2}\right)$ product ratio of denitrification as controlled by available carbon substrates and nitrate concentrations. Agriculture Ecosystem and Environment, 147, 4-12. https://doi.org/10.1016/j.agee.2011.06.022

Singh, S., Yadav, Y., \& Juneja, S. K. (2017). Leaf Litter Utilization through Composting: A Review. Journal of Agroecology and Natural Resource Management, 4(5), 398-402.

Singla, A., Iwasa, H., \& Inubushi, K. (2014). Effect of biogas digested slurry based-biochar and digested liquid on $\mathrm{N}_{2} \mathrm{O}, \mathrm{CO}_{2}$ flux and crop yield for three continuous cropping cycles of komatsuna (Brassica rapa var. perviridis). Biology and Fertility of Soils, 50, 1201-1209. https://doi.org/10.1007/s00374-014-0950-7

Soumare, A., Sall, S. N., Manga, G. A., Hafidi, M., Ndoye, I., \& Duponnois, R. (2012). Effect of eucalyptus (Eucalyptus camaldulensis) and maize (Zea mays) litter on growth, development, mycorrhizal colonization and roots nodulation of Arachis hypogaea. African Journal of Biotechnology, 11(93), 15994-16002. https://doi.org/10.5897/AJB12.1751

Tiquia, S. M. (2010). Reduction of compost phytotoxicity during the process of decomposition. Chemosphere, 79, 506-512. https://doi.org/10.1016/j.chemosphere.2010.02.040

Van Groenigen, J. W., Kuikman, P. J., de Groot W. J. M., \& Velthof, G. L. (2005). Nitrous oxide emission from urine-treated soil as influenced by urine composition and soil physical conditions. Soil Biology and Biochemistry, 37, 463-473. https://doi.org/10.1016/j.soilbio.2004.08.009

Van Zwieten, L., Kimber, S., Morris, S., Chan, K. Y., Downie, A., Rust, J., ... Cowie, A. (2010). Effect of biochar from slow pyrolysis of paper mill waste on agronomic performance and soil fertility. Plant and Soil, 327, 235-246. https://doi.org/10.1007/s11104-009-0050-x

Wacal, C., Ogata, N., Basalirwa, D., Handa, T., Sasagawa, D., Acidri, R., ... Nishihara, E. (2019). Growth, Seed Yield, Mineral Nutrients and Soil Properties of Sesame (Sesamum indicum L.) as Influenced by Biochar Addition on Upland Field Converted from Paddy. Agronomy, 9(2), 55. https://doi.org/10.3390/agronomy 9020055

\section{Copyrights}

Copyright for this article is retained by the author(s), with first publication rights granted to the journal.

This is an open-access article distributed under the terms and conditions of the Creative Commons Attribution license (http://creativecommons.org/licenses/by/4.0/). 